\title{
Para onde vai o pensamento turístico?
}

\section{Where does the touristic thought go?}

\author{
Vander Valduga (VALDUGA, V.)
}

RESUMO - O texto faz uma breve reflexão sobre o turismo e suas implicações práticas e acadêmicas. Propõe um repensar turístico a partir da ideia do fim do regime disciplinar tradicional, relacionando o contexto de formação docente e profissional na área.

Palavras-chave: Turismo; Crise paradigmática; Formação profissional.

ABSTRACT - The text is a brief reflection about tourism and its practical and academic implications. It proposes a touristic rethinking from the idea of the end of the traditional disciplinary regime, relating the context of the teacher's and professional formation in the area.

Key words: Tourism; Paradigmatic crisis; Professional formation.

\footnotetext{
* Graduação em Turismo (Bacharelado) pela Universidade de Caxias do Sul (UCS). Mestrado em Turismo pela Universidade de Caxias do Sul (UCS). Doutorado em Geografia pela Universidade Federal do Rio Grande do Sul (UFRGS). Professor e Pesquisador do Departamento de Turismo da Universidade Federal do Paraná. Endereço para correspondência: Departamento de Turismo (UFPR), Rua Dr. Faivre, 405, $3^{\circ}$ andar, Curitiba, Paraná, CEP: 80060-140. Telefone [41] 8512 7550. E-mail: vandervalduga@gmail.com
} 
O tema central que suscitou esse breve artigo de caráter opinativo foi o chamado “apagão de mão de obra nos serviços", aclamado cotidianamente pelos setores mais conservadores da mídia nacional, especialmente em tempos de grandes eventos. Embora o apagão de mão de obra não seja o tema central abordado aqui, é preciso analisar algumas de suas interfaces.

É fato que a demanda pelos cursos de turismo, tanto em nível de graduação quanto em nível técnico e tecnológico, com poucas exceções, decresce semestralmente e pode-se assistir a quase extinção dos cursos de turismo das instituições de ensino privadas em todo o Brasil. Depois do frenesi desordenado de expansão desses cursos na primeira década desse século, o mercado passa pelo seu (des)ajuste, reflexo, também, da falta de planejamento dos setores educacionais brasileiros que, infelizmente, continuam aprovando cursos de turismo Brasil afora, numa crença desenvolvimentista ancorada na populista panaceia turística. $\mathrm{O}$ mercado turístico, como não poderia ser diferente, exige a mais-valia e as deficiências de formação são compartilhadas pela rede turística em sentido ampliado. A profisssão "turismólogo" tem seu valor diminuído. O problema parece não residir na trivialidade aparente, portanto, é necessária uma reflexão.

O apagão de mão de obra em serviços, analisado pelo viés da objetividade parcial midiática, polariza a discussão entre o sim e o não, entre o a favor e o contra, numa tentativa cômoda de manter padrões salariais compatíveis com a baixa escolaridade média dos profissionais de serviços. O segmento se mantém, assim, com altos padrões de rotatividade, atraindo cada vez menos pessoas capacitadas que optam por migrar à indústria ou que abrem negócios próprios. Inúmeros debates podem decorrer dessa breve observação, tanto do ponto de vista da opção brasileira de "desenvolvimento" quanto da formação acadêmica e profissional. A segunda opção será brevemente abordada aqui.

O turismo vive sua crise. Crise mercadológica? Não. O turismo vive sua crise epistemológica e é preciso reconhecê-la. A crise do turismo é de ordem racional e fragmentária, da lisura positivista por resultados objetivos ou numa falsa ruptura dogmática entre mercado e academia. Um tema recorrente entre docentes e pesquisadores da área é o debate sobre a formação acadêmica e se ela deve ou não servir ao mercado. Essa simples indagação revela, de face, a fragmentação do pensamento, como se houvesse uma realidade do mercado por um lado e outra realidade da academia 
por outro e assim por diante. No mesmo sentido, a maioria dos cursos de turismo continua seguindo uma lógica disciplinar, recortes de áreas de conhecimento ou ciências que, em tese, dariam conta do fenômeno turístico. O resultado disso é a perfeita reprodução de todos os modelos vigentes ou padrões sociais estabelecidos, retroalimentando o sistema que depõe sempre contra ou a favor do indivíduo e não do sujeito.

As "reformas" curriculares que visam à atualização de matrizes curriculares mais parecem "colchas de retalhos" e permanecem distantes dos reais problemas do turismo. O pensar turístico exige a reforma de pensamento e não simplesmente de unidades curriculares. É preciso uma reengenharia. A reforma do pensamento começa por pensar o objeto científico do turismo. É comum encontrar pesquisadores que desconhecem o objeto de estudos do turismo ou ignoram a discussão, diminuindo sua relevância. Mesmo em programas stricto sensu de turismo, raras são as oportunidades de pensar tal objeto. Comumente as discussões se resumem a metodologias, sem debates sobre métodos e, frequentemente, assume-se como avanço científico no turismo pequenas adaptações de metodologias já utilizadas, passando a margem do real avanço científico. Pensar o objeto do turismo reside no âmago do sujeito do conhecimento em turismo, isto é, a natureza de todo o conhecimento consiste na constituição de uma relação entre o sujeito e o objeto, nos termos de Piaget ${ }^{1}$. É um princípio dialógico, de complementaridade, antagonismo e interdependência. Qual o sentido de pesquisar turismo sem referência ao seu objeto de estudos? Pesquisar turismo para quê? Para quem? Qual o objeto central do turismo?

O presente texto filia-se à corrente de pensamento crítica do turismo, em que a preocupação com o olhar do turismo se torna fundamental tanto quanto o olhar do turismólogo. É verdade que muita coisa mudou depois do sistema turístico de Leiper², entretanto, como o otimismo não é pressuposto acadêmico, pode-se dizer que há muito que fazer. É obrigação de cursos stricto sensu refletir sobre sua área ao mesmo tempo em que é obrigação proporcionar a formação docente. Inúmeros mestres e doutores deixam seus cursos sem quaisquer reflexões ou práticas sobre a docência e isso se

\footnotetext{
${ }^{1}$ PIAGET, J. Les problèmes principaux de l'épistémologie des mathématiques. In: Piaget, J. (Org.). Logique et Connaissance Scientifique. Dijon, Gallimard, 1967. p. 554-595.

${ }^{2}$ LEIPER, N. The tourism system. Massey University Press, 1990.
} 
agrava no turismo, pois retroalimenta o mesmo sistema que é, sobretudo, social. Novas estruturas curriculares são necessárias em turismo, obedecendo a um perfil formativo construído a partir de estruturas diferentes, com problemáticas e soluções diferenciadas, com base na incerteza, em construtos, fora da zona de conforto acadêmica. Muitos cursos de graduação em turismo são completamente provincianos ou baseados em manuais e na crença da transformação local por meio do turismo, sem diálogos com outras áreas, numa crença disciplinar fragmentada.

Pensar sobre o objeto, refletir, criticar e romper paradigmas poderá refletir numa prática docente que retroalimente o sistema educacional em turismo noutro sentido. A amplitude do turismo como objeto do conhecimento comporta, também, não enquadrálo no regime disciplinar tradicional e, talvez, essa ruptura paradigmática possa permitir pensá-lo a partir de outras bases, de forma pedagógica e reflexiva. Contudo, inúmeras dificuldades precisariam ser enfrentadas especialmente no âmbito burocrático e estrutural das universidades, que ainda são regidas pela disciplina da disciplina, pelos gabinetes, pelas afinidades políticas de grupos e pela proteção e conforto que a manutenção do status quo proporciona.

Repensar o turismo em tempos de apagão pode clarear diversos pontos ainda praticamente ignorados, como novas abordagens a partir de categorias maiores como as relações entre sujeitos, tempos e espaço turísticos. É preciso, ainda, "descolonizar-se" no turismo, sob pena de se permanecer aplaudindo de pé modelos de análise e receituários oriundos das relações centro-periferia. 